\title{
KEPUASAN KONSUMEN MELALUI KUALITAS PRODUK SIMCARD TELKOMSEL
}

\author{
Kurniawan Aji Prakasa ${ }^{1}$, Desy Arisandy ${ }^{2}$, \\ Mahasiswa Universitas Bina Darma ${ }^{1}$, Dosen Universitas Bina Darma ${ }^{2}$ \\ Jalan Jenderal Ahmad Yani No.3 Palembang \\ Sur-el : ajikafc@gmail.com ${ }^{1}$, desy.arisandy@binadarma.ac.id ${ }^{2}$,
}

\begin{abstract}
This research was conducted to find out the relationship between product quality and user customer satisfaction of Telkomsel simcard in the students of Bina Darma Palembang University. The hypothesis proposed in this study is that there is a relationship between product quality and user customer satisfaction of Telkomsel simcard in the students of Bina Darma Palembang University. Subjects in this study amounted to 186 students of Bina Darma Palembang University. The sample technique used in this study is purposive sampling technique. The measuring instrument used is the scale of product quality and customer satisfaction. The analysis technique used is simple regression using SPSS version 20.0. The results of the analysis show that the correlation coefficient $(R)=0.194$ with the score obtained is $(R$-square $)=0.038$ and $p=0.008(p<0.05)$ which means that the proposed hypothesis is accepted. These results indicate that there is a significant relationship between product quality and user customer satisfaction of Telkomsel simcard in the students of Bina Darma Palembang University. The contribution of the product quality variable to the consumer satisfaction variable is $3.8 \%$.
\end{abstract}

Keywords: Product Quality, Customer Satisfaction, Telkomsel Simcard

Abstrak : Penelitian ini dilakukan untuk mengetahui adanya hubungan antara kualitas produk dengan kepuasan konsumen pengguna simcard Telkomsel pada mahasiswa Universitas Bina Darma Palembang. Hipotesis yang diajukan dalam penelitian ini adalah bahwa ada hubungan antara kualitas produk dengan kepuasan konsumen pengguna simcard Telkomsel pada mahasiswa Universitas Bina Darma Palembang. Subjek dalam penelitian ini berjumlah 186 mahasiswa Universitas Bina Darma Palembang. Teknik sampel yang digunakan pada penelitian ini adalah teknik purposive sampling. Alat Ukur yang digunakan adalah skala kualitas produk dan kepuasan konsumen. Teknik analisis yang digunakan yaitu regresi sederhana dengan menggunakan bantuan SPSS versi 20.0. Hasil analisis menunjukkan koefisien korelasi $(R)=0,194$ dengan skor yang didapatkan yaitu ( $R$-square) $=0,038$ dan $p=0,008(p<0,05)$ yang berarti hipotesis yang diajukan diterima. Hasil ini menunjukkan bahwa ada hubungan yang signifikan antara kualitas produk dengan kepuasan konsumen pengguna simcard Telkomsel pada mahasiswa Universitas Bina Darma Palembang Kontribusi variabel kualitas produk dengan variabel kepuasan konsumen yaitu $3,8 \%$.

Kata Kunci : Kualitas Produk, Kepuasan Konsumen, Kartu Telkomsel

\section{PENDAHULUAN}

Salah satu kekuatan paling dramatis yang membentuk kehidupan manusia adalah teknologi. Teknologi menghasilkan seperti telepon seluler dan permainan video yang memiliki dampak baik dan buruk sekaligus. Teknologi menciptakan konsekuensi jangka panjang yang besar dan tidak selalu dapat 
diperkirakan (Kotler dan Keller, 2009). Perkembangan yang terjadi dengan cepat di bidang komunikasi membuat para ahli menyebutnya sebagai revolusi komunikasi. Perubahan yang cepat ini didorong oleh adanya berbagai penemuan di bidang teknologi sehingga apa yang dulu merupakan kendala dalam kegiatan komunikasi, sekarang sudah terbuka lebar (Zamroni, 2009).

Teknologi komunikasi ini sangat bermanfaat di kalangan mahasiswa untuk saling berkomunikasi dengan teman-temannya melalui aplikasi pesan singkat seperti BBM, Line, Whatsapp. Melalui media-media tersebut membuat mahasiswa praktis saat berkomunikasi jarak jauh dan bisa mendapatkan informasi tanpa bertemu tatap muka. Selain untuk media berkomunikasi, sangat bermanfaat juga untuk kebutuhan sehari-hari seperti browsing internet. Browsing internet merupakan salah satu kebutuhan utama mahasiswa dalam menjalani studi selama di kampus.

Mahasiswa Universitas Bina Darma mempunyai banyak kebutuhan dalam hal komunikasi informasi. Mahasiswa biasa diberikan tugas oleh dosen yang berkaitan dengan internet, seperti mendapatkan tugas di elearning dan mencari materi-materi kuliah melalui internet. Universitas Bina Darma sendiri merupakan kampus yang berbasis IT dimana di dalam kampus terdapat jaringan wifi yang bisa digunakan mahasiswa untuk browsing internet. Mahasiswa terkadang sangat susah untuk terhubung ke jaringan wifi dikarenakan wifi yang ada di kampus
Universitas Bina Darma mempunyai batas pemakaian dalam sehari dan ketika aktif kuliah banyak mahasiswa yang memakai jaringan wifi di kampus, sehingga membuat mahasiswa susah untuk terhubung ke jaringan tersebut. Jaringan wifi di kampus Bina Darma juga sering hilang dan membuat mahasiswa sedikit kecewa karena mereka yang lagi menikmati jaringan wifi untuk browsing atau download file jadi terhambat. Untuk mengatasi hal tersebut, mahasiswa membutuhkan fasilitas yang bisa mendukung aktivitas mereka. Fasilitas yang dibutuhkan salah satunya adalah operator seluler. Operator seluler sekarang menjadi sorotan penting untuk kebutuhan mahasiswa, tanpa adanya operator seluler mahasiswa sangat kebingungan dalam melakukan aktivitas komunikasi.

Ada berbagai macam operator seluler di Indonesia yaitu ada indosat, 3 (Tri), XL, smartfren dan telkomsel. Persaingan antar operator seluler dalam mempertahankan pelanggan dan menarik konsumen baru merupakan satu keuntungan bagi konsumennya. Berdasarkan hasil survey pada tanggal 7 Maret 2018 dengan membagikan 166 kuisioner kepada mahasiswa Universitas Bina Darma Palembang, didapatkan 56\% mahasiswa pengguna telkomsel, $25 \%$ pengguna 3 (Tri), $5 \%$ pengguna smartfren, $4 \%$ pengguna indosat, $3 \%$ pengguna $\mathrm{XL}$, dan $7 \%$ mahasiswa pengguna axis. Berdasarkan hasil survey tersebut telkomsel merupakan provider yang banyak digunakan oleh mahasiswa. Berdasarkan grafik diatas, dapat disimpulkan bahwa rata-rata pengguna simcard Telkomsel 
pada Mahasiswa di Universitas Bina Darma berusia 20-22 tahun, sudah lebih dari lima tahun menggunakan Telkomsel. Mahasiswa banyak mengatakan bahwa jaringan Telkomsel kencang dan memiliki kualitas yang bagus.

\section{Adriansyah (Anonim, 2017)} mengatakan bahwa Telkomsel secara konsisten melayani negeri, menghadirkan akses telekomunikasi kepada masyarakat Indonesia yang tersebar dari sabang sampai merauke. Saat ini Telkomsel adalah operator seluler terbesar di Indonesia dengan 178 juta pelanggan dan untuk melayani pelanggannya yang tersebar di seluruh Indonesia, termasuk juga di daerah terpencil dan pulau terluar serta daerah perbatasan Negara.

Selain tarif, telkomsel juga memberikan batas penggunaan yang singkat. Seperti paket harian yang hanya berlaku pada hari dimana konsumen melakukan pembelian paket tersebut. Telkomsel memberikan pembagian kuota regular, kuota malam dan kuota videomax. Mahasiswa sendiri lebih membutuhkan kuota internet regular 24 jam daripada yang lain. Kuota malam yang diberikan telkomsel mulai dari pukul 00:00 sampai dengan 07:00. Waktu malam tersebut biasa tidak terpakai oleh mahasiswa, karena waktu malam yang diberikan oleh telkomsel tersebut merupakan waktu istirahat bagi mahasiswa. Bahkan ada juga yang rela begadang demi menggunakan kuota malam telkomsel. Selain pembagian kuota malam, telkomsel juga memberikan pembagian kuota videomax.
Pembagian kuota videomax ini hanya menguntungkan bagi mahasiswa yang hobi menonton film-film kesukaannya karena kuota videomax ini bisa digunakan apabila konsumen sudah mendownload aplikasi viu yang bisa digunakan untuk menonton film-film. Dengan adanya kuota videomax ini mahasiswa tidak takut kalau kuota regularnya habis karena mereka bisa menonton film dengan menggunakan kuota videomax tersebut.

Kotler dan Keller (2009) mengatakan bahwa kepuasan konsumen merupakan fungsi kedekatan antara harapan dan kinerja anggapan produk. Jika kinerja tidak memenuhi harapan, konsumen kecewa. Jika memenuhi harapan, konsumen puas. Jika melebihi harapan, konsumen sangat puas. Perasaan ini menentukan apakah pelanggan membeli produk kembali dan membicarakan hal-hal menyenangkan atau tidak menyenangkan tentang produk itu kepada orang lain.

Kepuasan konsumen adalah persepsi konsumen bahwa harapannya telah terpenuhi atau terlampaui dengan membeli dan atau menggunakan produk tersebut (Wijayanti, 2017). Sejalan dengan itu, Day (Tjiptono, 2006) kepuasan atau ketidakpuasan pelanggan adalah respons pelanggan terhadap evaluasi ketidaksesuaian (disconfirmation) yang dirasakan antara harapan sebelumnya (atau norma kinerja lainnya) dan kinerja aktual produk yang dirasakan setelah pamakaiannya. Harapan konsumen akan semakin berkembang seiring dengan banyaknya informasi yang didapatkan pascakonsumsi. 
Kotler dan Keller (2009) yang menyatakan ada enam ciri-ciri kepuasan konsumen, yaitu: 1) tetap setia untuk waktu yang lebih lama, 2) membeli lagi ketika perusahaan memperkenalkan produk baru dan memperbaharui produk lama, 3) membicarakan hal-hal baik tentang perusahaan dan produknya kepada orang lain, 4) tidak terlalu memperhatikan merek pesaing dan tidak terlalu sensitif terhadap harga, 5) menawarkan ide produk atau jasa kepada perusahaan, 6) biaya pelayanannya lebih murah dibandingkan pelanggan baru karena transaksi dapat menjadi hal rutin.

Ternyata dari kepuasan yang dirasakan oleh mahasiswa ada juga yang merasakan ketidakpuasan dari produk Telkomsel. Peter dan Olson (Kristianto, 2011) menyebutkan bahwa ketidakpuasan konsumen muncul apabila harapan konsumen tidak terpenuhi yaitu apabila kinerja suatu produk yang diberikan tidak sesuai dengan yang diharapkan. Konsumen yang merasa tidak puas terhadap suatu produk, kemungkinan tidak akan melakukan pembelian ulang dan akan menceritakan pada konsumen yang lain

Kristianto (2011) menyebutkan bahwa dalam ketidakpuasan yang timbul pada konsumen, ada lima hal yang akan dilakukan konsumen yang mengambil tindakan jika merasa tidak puas yaitu akan melakukan complain kepada perusahaan, berhenti membeli produk tersebut, memperingatkan teman agar tidak menggunakan produk tersebut, complain kepada pemerintah, dan mengajukan tuntutan.
Zeithamil dan Bitner (Ningtias, 2017) menyatakan bahwa terdapat dua tingkat kepuasan konsumen, yaitu kepuasan konsumen pada tingkat rendah, kemungkinan besar para konsumen cenderung menjauhi perusahaan dan menyebar cerita jelek tentang perusahaan dan akan merasa mudah beralih ketika tawaran yang lebih baik muncul. Kepuasan konsumen pada tingkat tinggi, konsumen sangat mungkin membeli kembali dan bahkan menyeberluaskan kabar baik tentang perusahaan. Kesenangan atau kepuasan yang tinggi menciptakan suatu ikatan emosional dengan merek atau perusahaan tersebut dan tidak hanya terpaku pada pilihan yang masuk akal saja

Lupiyoadi (Harun, 2013) menyebutkan lima faktor utama yang perlu diperhatikan dalam kaitannya dengan kepuasan konsumen, antara lain 1) Kualitas Produk yaitu konsumen akan puas bila hasil evaluasi mereka menunjukkan bahwa produk yang mereka gunakan berkualitas, 2) Kualitas pelayanan yaitu konsumen akan merasa puas bila mendapatkan pelayanan yang baik atau yang sesuai dengan harapan, 3) Emosional yaitu konsumen merasa puas ketika orang memuji dirinya karena menggunakan merek yang mahal, 4) Harga yaitu produk yang mempunyai kualitas yang sama tetapi menetapkan harga yang relatif murah akan memberikan nilai yang lebih tinggi, 5) Biaya yaitu konsumen yang tidak perlu mengeluarkan biaya tambahan atau tidak perlu membuang waktu untuk mendapatkan suatu produk. 
Sejalan dengan itu Tjiptono (2006) mengatakan kepuasan pelanggan dapat menciptakan kesetiaan atau loyalitas pelanggan kepada perusahaan yang memberikan kualitas memuaskan.

Juran (Tjiptono, 2005) mendefinisikan kualitas sebagai kecocokan untuk pemakaian (fitness for use). Definisi ini menekankan orientasi pada pemenuhan harapan pelanggan. Sejalan dengan itu, Kotler (Nurtjahjanti, 2012) mendefinisikan kualitas produk sebagai kemampuan produk untuk melaksanakan fungsinya meliputi daya tahan, keandalan, ketepatan, kemudahan operasi, dan perbaikan serta atribut bernilai lainnya. Kualitas mengacu pada segala sesuatu yang menentukan kepuasan konsumen. Suatu produk yang dihasilkan dikatakan berkualitas apabila sesuai dengan keinginan pelanggan, dapat dimanfaatkan dengan baik, dan di produksi dengan cara yang baik dan benar.

$$
\text { Garvin (Nurtjahjanti, 2012), }
$$
menyebutkan bahwa terdapat delapan dimensi karakteristik yang digunakan oleh konsumen mempersepsi kualitas produk. Delapan dimensi karakteristik kualitas produk adalah sebagai berikut: 1) Performansi (performance) berkaitan dengan aspek fungsional dari produk. 2) Features berkaitan dengan pilihan-pilihan pengembangannya. Konsumen biasanya mendefinisikan nilai dalam bentuk fleksibilitas dan kemampuan untuk memilih feature yang ada, juga kualitas dari feature tersebut. 3) Keandalan (reliability) berkaitan dengan kemungkinan suatu produk melaksanakan fungsinya. Keandalan juga merupakan konsistensi dari kinerja yang dihasilkan suatu produk dari satu pembelian ke pembelian berikutnya. 4) Kesesuaian dengan spesifikasi (conformance) berkaitan dengan tingkat kesesuaian produk terhadap spesifikasi yang telah ditetapkan sebelumnya berdasarkan keinginan pelanggan. 5) Daya tahan, berkaitan dengan daya tahan dari produk atau ukuran hidup suatu produk (umur produk). 6) Kemampuan pelayanan (service ability) merupakan karakteristik yang berkaitan dengan kecepatan, keramahan atau kesopanan, kompetensi, kemudahan serta akurasi dalam perbaikan. 7) Estetika merupakan karakteristik yang bersifat subjektif sehingga berkaitan dengan pertimbangan pribadi dan refleksi dari preferensi atau pilihan individual. 8) Kualitas yang dirasakan (perceived quality) bersifat subyektif, berkaitan dengan reputasi (brand name, image).

Gitosudarmo (1994) menyebutkan bahwa produk yang dipasarkan merupakan senjata yang sangat bagus dalam memenangkan persaingan apabila memiliki mutu atau kualitas yang tinggi. Sebaliknya produk yang mutunya rendah akan sukar untuk memperoleh citra dari para konsumen.

Berdasarkan fenomena diatas, peneliti merumuskan masalah yang menarik untuk dikaji yaitu mengetahui "Apakah ada hubungan antara kualitas produk dengan kepuasan konsumen pengguna simcard telkomsel pada mahasiswa Universitas Bina Darma Palembang" 


\section{METODE PENELITIAN}

Identifikasi Variabel Penelitian terdir dari Variabel Tergantung : Kepuasan Konsumen, Variabel Bebas adalah Kualitas Produk

Definisi operasional variabel kepuasan konsumen adalah persepsi mahasiswa Universitas Bina Darma bahwa harapannya telah terpenuhi atau terlampaui dengan membeli dan atau menggunakan produk Telkomsel.

Kualitas produk adalah kemampuan produk Telkomsel untuk melaksanakan fungsinya meliputi daya tahan, keandalan, ketepatan, kemudahan operasi, dan perbaikan serta atribut bernilai lainnya. Kualitas produk tersebut sangat diharapkan oleh mahasiswa Universitas Bina Darma Palembang

Berdasarkan penjelasan di atas maka hipotesis penelitian ini adalah ada hubungan antara kualitas produk dengan kepuasan konsumen pengguna simcard Telkomsel pada mahasiswa Universitas Bina Darma Palembang

Adapun populasi pada penelitian ini adalah mahasiswa Universitas Bina Darma Palembang pengguna simcard Telkomsel. Sejalan dengan itu, Sujarwo (2014) menyatakan bahwa sampel adalah bagian dari populasi yang menjadi subjek penelitian dan akan diambil sebagai data penelitian.

Mahasiswa yang menggunakan simcard Telkomsel berjumlah 360. Bila mengacu pada tabel penentuan jumlah sampel dari populasi tertentu yang dikembangkan dari Isaac dan Michael dengan taraf kesalahan 5\% maka diperoleh sampel sebanyak 186 mahasiswa. Jadi sampel yang diperoleh itu mempunyai kepercayaan $95 \%$ terhadap populasi. Sebelum pelaksanaan penelitian dilakukan uji coba skala atau TO (Try Out) terlebih dahulu sebanyak 174 mahasiswa yang diambil, dari sisa populasi digunakan sebagai sampel penelitian.

Metode pengumpulan data merupakan suatu cara yang digunakan oleh peneliti untuk mendapatkan data. Metode pengumpulan data yang digunakan dalam penelitian ini adalah dengan metode skala. Azwar (2006) menjelaskan bahwa skala adalah perangkat pertanyaan yang disusun untuk mengungkap atribut tertentu melalui respon terhadap pertanyaan tersebut.

Skala yang digunakan dalam penelitian ini adalah bersifat tertutup, yaitu subjek diminta untuk memilihi salah satu dari beberapa pilihan jawaban yang tersedia. Skala kepuasan konsumen dan skala kualitas produk dalam penelitian ini menggunakan skala likert yang dibuat dalam bentuk checklist. Skala ini terdiri dari dua bentuk pernyataan, yaitu berupa pernyataan yang mendukung (favourable) dan pernyataan yang tidak mendukung (unfavourable).

Aitem-aitem dalam skala dibuat berdasarkan pada aspek-aspek tertentu dan disajikan dalam blue print. Blue print skala kepuasan konsumen yang dibuat oleh penulis berdasarkan pada aspek kepuasan konsumen yang dikemukakan oleh acuan aspek-aspek kepuasan konsumen yang dikemukakan oleh Wijayanti (2017) mengatakan bahwa aspek 
kepuasan konsumen adalah 1) Menghasilkan produk dengan mutu lebih baik. 2) Harga lebih ekonomis. 3) Pelayanan lebih baik dibandingkan pesaingnya, yang terdiri dari 60 butir aitem dengan 30 aitem pernyataan favourable dan 30 aitem pernyataan unfavourable yang harus direspon oleh subjek. .

Blue print Kualitas produk diukur menggunakan dimensi yang dikemukakan oleh Garvin (Nurtjahjanti, 2012), yaitu; 1) Performansi (performance); 2) Features; 3) Keandalan (reliability); 4) Kesesuaian dengan spesifikasi; 5) Daya tahan; 6) Kemampuan pelayanan; 7) Estetika; 8) Kualitas yang dirasakan yang disusun dalam 64 pernyataan yang terdiri dari 32 pernyataan favourable dan 32 pernyataan unfavourable.

Validasi skala psikologi adalah membuktikan bahwa struktur seluruh aspek, indikator, dan aitem - aitemnya memang membentuk suatu konstrak yang akurat bagi atribut yang diukur (Azwar, 2012). Koefisien validitas mempunyai makna jika bergerak dari 0,00 sampai 1,00. Koefisien yang berkisar antara 0,30 sampai dengan 0,50 telah dapat memberikan kontribusi yang baik dan sudah dianggap memuaskan.

Reliabilitas adalah salah satu ciri instrumen ukur yang berkualitas baik, yaitu mampu menghasilkan skor yang cermat dengan eror pengukuran kecil. Reliabilitas mengacu kepada kepercayaan atau konsistensi hasil ukur yang mengandung makna seberapa tinggi kecermatan pengukuran. Pengukuran dikatakan tidak cermat bila eror pengukurannya terjadi secara random antara skor individu yang satu dengan yang lain terjadi eror yang tidak konsisten dan bervariasi, sehingga perbedaan skor yang diperoleh lebih banyak ditentukan oleh eror, bukan oleh perbedaan yang sebenarnya. Implikasinya, pengukuran yang tidak cermat berarti juga tidak konsisten dari waktu ke waktu (Azwar, 2006).

Semakin tinggi koefisien korelasi antara hasil ukur dari dua tes yang pararel, berarti konsistensi di antara keduanya semakin baik dan kedua alat ukur itu disebut sebagai alat ukur yang reliabel. Sebaliknya, apabila korelasi antara hasil dari dua alat ukur yang pararel ternyata tidak tinggi, maka disimpulkan bahwa reliabilitasnya rendah. Koefisien reliabilitas berada dalam rentang angka dari 0 sampai dengan 1,00. Sekalipun bila koefisien reliabilitas semakin tinggi mendekati angka 1,00 berarti pengukuran semakin reliabel, namun dalam kenyataan pengukuran psikologi koefisien sempurna yang mencapai angka 1,00 belum pernah dijumpai (Azwar, 2006).

Metode analisis yang digunakan dalam penelitian ini adalah analisis regresi sederhana (simple regression), karena dalam penelitian ini terdapat satu variabel bebas dan satu variabel tergantung. Analisis regresi sederhana digunakan untuk mengetahui korelasi antara kualitas produk dengan kepuasan konsumen pengguna simcard Telkomsel pada mahasiswa Universitas Bina Darma Palembang. Uji relibilitas yang digunakan dalam penelitian ini menggunakan teknik Alpha Cronbach dengan bantuan program komputer SPSS 20.0 (Statistical Package Sosial Science). 
Analisis data yang digunakan dalam penelitian ini adalah analisis statistik. Sebelum dilakukan uji hipotesis terlebih dahulu dilakukan uji prasyarat yaitu uji normalitas dan uji linieritas.

\section{HASIL DAN PEMBAHASAN}

Pengukuran validitas ini dilakukan dengan cara menghitung koefisien skor subjek aitem yang bersangkutan. Melalui indeks daya beda aitem, maka dapat ditemukan aitem-aitem yang layak untuk digunakan dan aitem-aitem yang tidak layak (gugur) dalam penelitian. Pengujian validitas aitem-aitem alat ukur dalam penelitian ini menggunakan teknik Alpha Cronbach dengan batas minimum koefisien korelasi sudah dianggap memuaskan jika mencapai 0,30 (Azwar, 2006).

Skala kepuasan konsumen yang berjumlah 60 aitem kemudian dilakukan analisis aitem, peneliti menggunakan batas minimum koefisien korelasi 0,30 sehingga diperoleh 47 aitem yang valid dan 13 aitem yang gugur dimana dilakukan analisis sebanyak empat kali.

Skala kualitas produk yang berjumlah 64 aitem dan terdiri dari 32 pernyataan favourable dan 32 pernyataan unfavourable telah dilakukan analisis validitas dengan batas minimum koefisien korelasi 0,30. Sehingga diperoleh 46 aitem yang valid dan 18 aitem yang gugur dimana dilakukan analisis sebanyak tiga kali.

Uji normalitas dari kedua data yang diperoleh melalui alat ukur yang dibuat oleh peneliti berdistribusi normal karena memenuhi kaidah $\mathrm{p}>0,05$, dapat dilihat dari nilai $\mathrm{p}$ alat ukur tersebut yaitu kepuasan konsumen $\mathrm{p}=$ $0,068(\mathrm{p}>0,05)$ dengan $\mathrm{KS}-\mathrm{Z}=1,301$ dan kualitas produk nilai $\mathrm{p}=0,609(\mathrm{p}>0,05)$ dengan $\mathrm{KS}-\mathrm{Z}=0,761$

Uji Linieritas merupakan uji yang dilakukan untuk mengetahui hubungan antara variabel bebas yaitu kualitas produk dan variabel tergantung yaitu kepuasan konsumen. Kaidah yang digunakan adalah jika $\mathrm{p}<0,05$ berarti hubungan antara kedua variabel adalah linier, jika $\mathrm{p}>0,05$ maka hubungan antara kedua variabel tidak linier. Berdasarkan koefesien yang menunjukkan hubungan antara variabel bebas dan variabel terikat nilai $\mathrm{F}=$ 7,227 dan $p=0,008$. Nilai $p$ merupakan nilai yang menunjukkan seberapa linier hubungan antara variabel bebas dan variabel terikat. Nilai $\mathrm{p}=0,008<0,05$ sehingga menunjukkan bahwa terdapat hubungan yang linier antara kualitas produk dengan kepuasan konsumen.

Berdasarkan hasil yang diperoleh nilai korelasi antara variabel kualitas produk dengan kepuasan konsumen yaitu $\mathrm{R}=0,194$ dengan nilai $\mathrm{R}$ square $=0,038$ dan $\mathrm{p}=0,008$ dimana $\mathrm{p}$ $<0,05$. Ini berarti bahwa ada hubungan yang signifikan antara kualitas produk dengan kepuasan konsumen pengguna simcard telkomsel pada mahasiswa Universitas Bina Darma Palembang. Besarnya sumbangan efektif yang diberikan oleh variabel kualitas produk dengan kepuasan konsumen adalah sebesar 3.8\% $\left(\mathrm{R}^{2}=0,038\right)$. Jadi masih terdapat $96.2 \%$ pengaruh dari faktor-faktor lain yang berhubungan dengan kepuasan konsumen namun tidak diteliti oleh peneliti.

Berdasarkan data yang didapatkan bahwa dari 186 subjek penelitian terdapat 55 
subjek perempuan dan 45 subjek laki-laki yang menggunakan simcard Telkomsel dengan pemakaian lebih dari lima tahun. Rata-rata usia penguna simcard Telkomsel di Universitas Bina Darma mulai dari usia 20-23 tahun. Pada tahap usia tersebut, seorang individu mulai memilih produk-produk berkualitas yang sesuai dengan harapan. Kotler dan Keller (2009) mengatakan bahwa semakin tinggi tingkat kualitas, semakin tinggi tingkat kepuasan konsumen. Dalam membeli suatu produk, seorang konsumen mungkin mendeteksi adanya suatu kekurangan. Konsumen akan merasa tidak puas jika suatu produk tidak sesuai harapan, konsumen akan merasa puas jika suatu produk sesuai harapan, dan konsumen akan merasa sangat puas jika suatu produk melebihi harapan (Rangkuti, 2002).

Selanjutnya peneliti juga telah
melakukan perhitungan statistic untuk membuktikan bahwa terdapat hubungan yang sangat signifikan antara kualitas produk dengan kepuasan konsumen pengguna simcard Telkomsel pada mahasiswa Universitas Bina Darma Palembang. Analisis dilakukan dengan menggunakan uji regresi sederhana yang hasilnya menunjukkan adanya penerimaan terhadap hipotesis yang diajukan. Hasil tersebut dapat dilihat dari nilai koesifien korelasi $\mathrm{R}=0,194$ dengan nilai signifikansi $(\mathrm{p})$ $=0,008$ atau dengan kata lain $(p)<0,05$. Ini menunjukkan bahwa ada hubungan yang signifikan antara kualitas produk dengan kepuasan konsumen pengguna simcard Telkomsel pada mahasiswa Universitas Bina
Darma Palembang. Berdasarkan data yang didapat di lapangan bahwa kualitas produk Telkomsel yang rendah karena tarifnya yang mahal serta kuota internet yang cepat habis sehingga membuat kepuasan mahasiswa juga rendah itu artinya kedua variabel berkorelasi positif dimana kedua variabel tersebut samasama rendah.

Besarnya nilai sumbangan efektif kualitas produk (variabel bebas) dengan kepuasan konsumen (variabel terikat) adalah nilai $\mathrm{R}$ square $=0,038$ atau $3,8 \%$. Berdasarkan hasil sumbangan efektif tersebut menunjukan bahwa kualitas produk berpengaruh positif terhadap kepuasan konsumen pengguna simcard Telkomsel pada mahasiswa Universitas Bina Darma Palembang. Dari hasil analisa data tersebut, kualitas produk hanya menyumbang sebesar 3,8\% terhadap kepuasan konsumen dan sisanya $96,2 \%$ ditentukan oleh faktor- faktor yang tidak diteliti dalam penelitian ini, seperti yang disebutkan Lupiyoadi (Harun, 2013) yaitu faktor kualitas pelayanan, emosional, harga, dan biaya. Tetapi dengan nilai sumbangan efektif yang kecil hanya menyumbang $3,8 \%$ itu disebabkan karena Telkomsel mengalami penurunan dimana semakin banyaknya persaingan antar provider untuk memuaskan konsumennya baik itu dari kualitas produk, tarif, serta promopromo yang diberikan kurang sesuai harapan konsumen.

Kotler dan Keller (2009) mengatakan bahwa kepuasan konsumen merupakan fungsi kedekatan antara harapan dan kinerja anggapan produk. Jika kinerja tidak memenuhi harapan, konsumen kecewa. Jika memenuhi harapan, 
konsumen puas. Jika melebihi harapan, konsumen sangat puas. Perasaan ini menentukan apakah pelanggan membeli produk kembali dan membicarakan hal-hal menyenangkan atau tidak menyenangkan tentang produk itu kepada orang lain. Peter dan Olson (Kristianto, 2011) menyebutkan bahwa ketidakpuasan konsumen muncul apabila harapan konsumen tidak terpenuhi yaitu apabila kinerja suatu produk yang diberikan tidak sesuai dengan yang diharapkan. Konsumen yang merasa tidak puas terhadap suatu produk, kemungkinan tidak akan melakukan pembelian ulang dan akan menceritakan pada konsumen yang lain

Zeithamil dan Bitner (Ningtias, 2017) kepuasan konsumen pada tingkat rendah kemungkinan besar para konsumen cenderung menjauhi perusahaan dan menyebar cerita jelek tentang perusahaan dan akan merasa mudah beralih ketika tawaran yang lebih baik muncul. Adapun bentuk perilaku berdasarkan aitem yang mendukung bahwa mahasiswa mengatakan produk Telkomsel itu mahal, ada sebagian mahasiswa yang masih menggunakan tetapi tidak merekomendasikan produk tersebut ke teman-temannya serta ada yang memilih tidak menggunakan produk Telkomsel lagi.

Kepuasan konsumen pada tingkat tinggi, konsumen sangat mungkin membeli kembali dan bahkan menyeberluaskan kabar baik tentang perusahaan. Kesenangan atau kepuasan yang tinggi menciptakan suatu ikatan emosional dengan merek atau perusahaan tersebut dan tidak hanya terpaku pada pilihan yang masuk akal saja.
Berdasarkan hasil deskripsi kategorisasi kepuasan konsumen bahwa dari sebanyak 186 mahasiswa pengguna simcard Telkomsel di Universitas Bina Darma yang dijadikan subjek penelitian, terdapat 83 mahasiswa atau 44,6\% yang memiliki kepuasan yang tinggi dan 103 mahasiswa Universitas Bina Darma atau 55,4\% memiliki tingkat kepuasan yang rendah. Sehingga dapat disimpulkan rata-rata mahasiswa Universitas Bina Darma memiliki tingkat kepuasan yang rendah.

Hal ini tampak dari bentuk kepuasan mahasiswa pada variabel kepuasan konsumen memiliki persentase yang rendah. Berdasarkan hasil survey awal dimana subjek penelitian yang telah menggunakan Telkomsel lebih dari lima tahun dimana pada saat menggunakan beberapa tahun itu produk Telkomsel sedang bagus-bagus nya memberikan pelayanan yang terbaik untuk konsumennya, itulah yang membuat mahasiswa tertarik menggunakan Telkomsel tetapi berdasarkan hasil penelitian yang dilakukan peneliti ditahun 2018 serta data yang didapatkan berdasarkan jawaban responden pada kuesioner, secara keseluruhan mahasiswa memiliki kepuasan yang rendah, tercermin pada besarnya nilai rata-rata total sebesar 55,4\% yang memiliki kategori rendah.

Telkomsel mengalami penurunan dimana semakin banyaknya persaingan antar provider untuk memuaskan konsumennya baik itu dari kualitas produk, tarif, serta promopromo yang diberikan. Hal ini yang membuat tingkat kepuasan mahasiswa rendah terhadap produk Telkomsel. Mahasiswa tidak tertarik 
dengan promo-promo yang diberikan telkomsel karena promo yang diberikan masih tergolong mahal untuk kalangan mahasiswa. Mahasiswa juga mengeluhkan kuota internet yang cepat habis sehingga membuat aktivitas browsing dan download menjadi terhambat.

Jadi itulah alasan subjek masih menggunakan produk Telkomsel. Dapat disimpulkan bahwa dari 186 mahasiswa Universitas Bina Darma yang dijadikan subjek penelitian, terdapat 55,4\% atau 103 mahasiswa yang memiliki kepuasan yang rendah.

\section{Gitosudarmo (1994) menyebutkan} bahwa produk yang dipasarkan merupakan senjata yang sangat bagus dalam memenangkan persaingan apabila memiliki mutu atau kualitas yang tinggi. Sebaliknya produk yang mutunya rendah akan sukar untuk memperoleh citra dari para konsumen.

\section{Kategorisasi kualitas produk} menunjukan bahwa dari 186 mahasiswa yang dijadikan subjek penelitian, ada 88 mahasiswa $(47,3 \%)$ yang menyatakan tingkat kualitas produk yang mereka gunakan tinggi dan 98 mahasiswa $(52,7 \%)$ menyatakan tingkat kualitas produk yang mereka gunakan rendah. Sehingga dapat disimpulkan rata-rata mahasiswa Universitas Bina Darma menyatakan tingkat kualitas produk yang mereka gunakan rendah.

Hal ini menunjukan bahwa kualitas produk telkomsel sendiri memiliki tingkat kualitas yang rendah dimana berdasarkan aitem yang mendukung bahwa Telkomsel memiliki tarif yang mahal, kuota internet yang cepat habis serta sedikitnya promo yang diberikan.
Promo yang diberikan telkomsel tidak sesuai dengan harapan mahasiswa karena promo yang diberikan masih tergolong mahal dan setiap simcard konsumen mempunyai promo yang berbeda. Selain itu, Telkomsel memberikan batas waktu singkat dalam pembelian paket itu membuat mahasiswa kurang puas dalam menggunakan produk telkomsel.

Penelitian mengenai kualitas produk diteliti oleh Syaparilwadi dan Wardana (2015) dengan judul pengaruh kualitas produk terhadap kepuasan konsumen pelanggan pada perusahaan konveksi fazry, penelitian ini bertujuan untuk mengetahui dan menguji pengaruh kualitas produk terhadap kepuasan konsumen pelanggan pada perusahaan konveksi fazry. Penelitian ini menggunakan metode penelitian kuantitatif kepada 100 responden dengan pendekatan deskriptif dengan teknik regresi linear sederhana. Data premier dikumpulkan melalui metode survey terhadap 100 responden mengunakan teknik Accidental Sampling. Hasil yang didapat bahwa kualitas produk termasuk dalam kategori tinggi, dengan persentase $73 \%$ dan kepuasan konsumen termasuk dalam kategori tinggi, dengan persentase $76 \%$.

Dalam penelitian ini penulis lebih melihat apakah ada hubungan antara kualitas produk dengan kepuasan konsumen pengguna simcard Telkomsel pada mahasiswa Universitas Bina Darma Palembang. Berdasarkan uraian diatas maka dapat disimpulkan bahwa hipotesis dalam penelitian ini diterima, adapun bunyi hipotesis dalam penelitian ini yaitu ada hubungan yang signifikan antara kualitas produk dengan 
kepuasan konsumen pengguna simcard Telkomsel pada mahasiswa Universitas Bina Darma Palembang.

\section{SIMPULAN}

Berdasarkan hasil yang diperoleh dari analisis data dan pembahasan, maka peneliti menarik kesimpulan bahwa ada hubungan yang signifikan antara kualitas produk dengan kepuasan konsumen pengguna simcard Telkomsel pada mahasiswa Universitas Bina Darma Palembang.

\section{DAFTAR RUJUKAN}

Azwar, S. (2006). Reliabilitas dan Validitas. Yogyakarta: Pustaka Pelajar

Anonim, (2017, Agustus 16). Telkomsel Terus Bangun Wilayah Perbatasan Negara. Diakses dari https://www.telkomsel.com/aboutus/news/telkomsel-terus-bangunwilayah-perbatasan-negara

Diyantoro, A.Y. (2015, Mei 15). Perbedaan Simcard, micro simcard dan USIM card. Diakses dari http://agunkzscreamo.blogspot.com/20 15/05/perbedaan-sim-card-dan-usimcard.html\#.WqCSyZqYPIU

Fitho, (2017, Februari 3). Pengertian Internet Sevice Provider (ISP) Beserta Fungsinya. Diakses dari http://www.tentangkomputer.com/umu $\mathrm{m} /$ pengertian-internet-serviceproviderbeserta-fungsinya/

Gitosudarmo, I. (1997). Manajemen Pemasaran.Yogyakarta: BPFEE

Harun, H.I. 2013. Hubungan Antara Kualitas Pelayanan Dengan Kepuasan Konsumen Pada Mahasiswa Pengguna Game Pointblank. Jurnal Fakultas Psikologi, 2, 1.
Kotler, P. dan Keller, K.L. (2009). Manajemen Pemasaran. Jilid 1. Edisi ke 13. Jakarta: Erlangga

Kristianto, P.L. 2011. Psikologi Pemasaran. Jilid 1. Edisi Pertama. Yogyakarta: CAPS

Nurtjahjanti, H. 2012. Hubungan Antara Persepsi Terhadap Harga dan Kualitas Produk Dengan Minat Membeli Produk Fashion OnlineShop Di Facebook Pada Mahasiswa Politeknik X Semarang. Jurnal Psikologi Undip, 11, 2,4-5.

Ningtias, S.D. (2017). Hubungan Antara Kualitas Pelayanan Dengan Kepuasan Konsumen Ojek Online (Gojek) di Kecamatan Seberang Ulu II Palembang (Skripsi, tidak diterbitkan). Fakultas Psikologi Universitas Bina Darma, Palembang

Rangkuti, F. (2002). Creating Effective Maeketing Plan. Jakarta: Gramedia Pustaka Utama

Sujarwo, S. (2014). Statistik I Buku Pembelajaran

Tjiptono, F. (2006). Manajemen Jasa. Edisi IV. Yogyakarta: Andi Offset

Wijayanti, T. (2017). Marketing Plan Dalam Bisnis. Edisi Third. Jakarta: Elex Media Komputindo

Zamroni, M. 2009. Perkembangan Teknologi Komunikasi dan Dampaknya Terhadap Kehidupan. Jurnal Dakwah,2, X, 197. 